anales de psicología / annals of psychology

2019 , vol. $35, \mathrm{n}^{\circ} 3$ (october), $514-520$

http://dx.doi.org/10.6018/analesps.35.3.354941
(C) Copyright 2019: Editum. Servicio de Publicaciones de la Universidad de Murcia. Murcia (Spain) ISSN print edition: 0212-9728. ISSN on line edition (http://revistas.um.es/analesps): 1695-2294.

On line edition License Creative Commons 4.0: BY-NC-ND

\title{
The evaluation of candidates in a personnel selection Process: Preference for experience over potential in unfavorable context
}

\author{
1 Universidad Autónoma de Madrid (Spain) \\ 2 IE School of Human Sciences and Technology, IE University (Spain) \\ 3 Universidad Francisco de Vitoria (Spain)
}

Borja Paredes ${ }^{1}$, David Santos ${ }^{2}$, Samuel del Olmo ${ }^{1}$, Beatriz Gandarillas ${ }^{3}$, and Pablo Briñol ${ }^{1}$

\begin{abstract}
Título: La evaluación de candidatos en un proceso de selección de personal: Preferencia por la experiencia sobre el potencial en contextos desfavorables.

Resumen: La presente investigación tiene como objetivo averiguar cómo se responde a distintos perfiles en la evaluación de candidatos de selección en función de contexto organizacional. Para ello, se realizó un experimento con una muestra de participantes formados en selección de personal. En primer lugar, los participantes recibieron un informe describiendo el contexto de una organización como favorable o desfavorable. A continuación, los participantes recibieron información sobre el candidato que fue descrito en términos de su alta experiencia previa o de su alto potencial como profesional. Despues de recibir información sobre la organización y el perfil, todos los participantes evaluaron al candidato. Se esperaba una mayor preferencia por la experiencia que por el potencial especialmente en situacioenes negativas. En linea con la hipótesis, los resultados mostraron que en condiciones de contexto organizacional desfavorable, las actitudes hacia el candidato fueron más favorables cuando éste fue presentado en términos de su alta experiencia ( $v$ s. su alto potencial). En condiciones de contexto organizacional favorable, las actitudes hacia el candidato no variaron en función de si su perfil destacaba la experiencia o el potencial.

Palabras clave: incertidumbre, potencial, experiencia, selección, actitudes.
\end{abstract}

\section{Responses to uncertainty}

People respond to unfavorable situations in ways that differ from how they do in favorable ones.. In general, in unfavorable situations, people tend to seek security (Nash, Mcgregor, \& Prentice, 2011).The scientific literature, both in social psychology and in organizational psychology, proposes several theoretical models that predict how people seek to compensate different forms of contextual uncertainty by looking for certainties (Erdogan, Kraimer, \& Liden, 2004; Hart, 2014; Heine, Proulx, \& Vohs, 2006; Jonas et al., 2014; Kay, Whitson, Gaucher, \& Galinsky, 2009; Martin, 1999; Mcgregor, Zanna, Holmes \& Spencer, 2001; Proulx, 2012; Van den Bos \& Lind, 2002). For example, in group contexts, Hogg (2012) argues that individuals tend to reduce their feelings of uncertainty or negativity by identifying with groups whose positions are extreme and that offer simple solutions and a sense of security. Identification with these types of groups allows individuals to define their identity and guides the way they think and behave. This research evaluates this type of strategy (security search in unfavorable

* Correspondence address [Dirección para correspondencia]: Borja Paredes Sansinenea. Department of Social Psychology and Methodology. Universidad Autónoma de Madrid. Ciudad Universitaria de Cantoblanco. Facultad de Psicología. C/ Ivan Pavlov, 6. Madrid, 28049 (Spain). E-mail: akparetto@gmail.com

(Article received: 18-6-2018; revised: 21-12-2018; accepted: 4-2-2019)
Abstract: The present research's main goal is to examine the evaluation of a job candidate as a function of his profile and the context of the organization. An experiment was conducted with a sample of participants trained in personnel selection. Participants first received a message describing that the future of a given organization was favorable or unfavorable. Then, all participants were asked to read the information about a potential job candidate for such organization. The candidate was described in terms of his previous experience or in terms of his potential as a professional. After receiving the information about the organization and the profile, all participants were asked to evaluate the job candidate. We expected that there would be a higher preference for experience relative to potential, particularly when the context was unfavorable. As predicted, results showed that under unfavorable contextual conditions, attitudes towards the candidate were more favorable when the job candidate was portrayed in terms of experience ( $v s$ potential). Under favorable contextual conditions, attitudes towards the candidate did not vary as a function of his profile.

Keywords: uncertainty, potential, experience, selection, attitudes.

situations) in a personnel selection context rather than in a context of group affiliation.

\section{Uncertainty in organizations}

In the field of organizations and the human resources management is also relevant to know how to deal with issues related to uncertain or unfavorable situations. On the one hand, organizations and the context in which they operate change constantly, distributing along a continuum. The periods of economic growth or stability can lead to instability and unfavorable perspectives (as happens with economic crises). On the other hand, candidates to join these organizations also can possess attributes that may be in different points of a continuum of changes, with profiles ranging from obtained achievements, to profiles focused on possible and potential future accomplishments.

\section{The profile of personnel selection candidates}

In general, most individuals would rather have certainties over uncertainties (e.g., Kahneman \& Tversky, 1979; Kruglanski, 1989). For example, consumer behavior research has revealed that people are willing to buy and pay more money when they feel certain about products than when they feel uncertain about them (E.g., Thomas \& Menon, 2007; Wan, Rucker, Tormala, \& Clarkson, 2010). In the field of at- 
titudes, research also reveals that certainty is seen as a catalyst that transforms attitudes into behavior - for example, it is more likely that favorable attitudes towards a politician held with certainty predict voting in favor of such candidate (Rucker, Tormala, Petty, \& Briñol, 2014). In this paper, it is proposed that candidates who offer greater security are preferred over those associated with doubts, especially in contexts in which the need for security is greater.

\section{The favorability of the organizational context}

In the organizational field, one key element of the context is the economic situation. Almost any factor related to the context that surrounds an organization can be understood in favorable or unfavorable terms (e.g., sector to which it belongs, level of competence, number of competitors, economic situation, availability of supplies; Duncan, 1972; Gertsen, Søderberg, \& Torp, 1998). Among all these factors, crisis and economic losses, unemployment or financial uncertainty are often evaluated as less favorable (Barnett \& Pratt, 2000; Gärling, Kirchler Lewis \& Go Raaij, 2009; Nelson \& Katzenstein, 2014). In this paper it is suggested that these negative and uncertain contexts will stimulate preference for options that are safe, including preference for candidates of whom there is no or little doubt.

\section{The interaction between the organizational context and the candidate's profile}

The present research examines the extent to which the evaluation of a candidate in a personnel selection context varies depending on the favorability of the organizational context as well as the candidate's profile. For this purpose, an experiment was carried out in which different participants with postgraduate training in personnel selection received information about the organizational context. Specifically, the context was described in terms of economic security (favorable) or in terms of economic crisis (unfavorable). On the other hand, the candidate was presented either with high experience or with high potential. After receiving background and profile information, all participants were asked to evaluate the candidate. As described below, the a priori hypothesis was that under unfavorable organizational conditions, participants would show a preference for the candidate who offers greater certainty, in this case, the one with experience vs. potential.

\section{Objectives and hypothesis}

As noted, the current research is framed within an experimental paradigm of personnel selection in which participants evaluate a candidate whose description is based in terms of experience $v s$. potential. The goal is to examine the extent to which evaluators show a greater preference for experience $v s$. potential of the candidate depending on the favorability of the context (favorable vs. unfavourable). We ex- pect an interaction between the two independent variables (context and profile of the candidate) such that when the context is unfavorable the experienced candidate is preferred over the potential one.

\section{Method}

\section{Participants}

One hundred twenty-three participants with training in personnel selection working for Human Resources in different professional companies (55.3\% women; Age $M=24.99$, $S D=2.46)$ participated anonymously and voluntarily in this investigation. At the time of the study, participants had completed their formative stage of the postgraduate training. . Eight participants did not answer all the variables and therefore were excluded from the analyses, leaving a final sample of one hundred and fifteen participants $(54.8 \%$ women; Age $M=25.03, S D=2.52)$. The sample was collected mainly following a convenience criterion (León \& Montero, 2003).

\section{Design}

A $2 \times 2$ between-subject factorial design was used, consisting of a first independent variable (Organizational context: "Unfavorable organizational context" vs. "Favorable organizational context") and a second independent variable (description of the candidate: "High experience" vs. "High potential") that were manipulated experimentally. Participants were randomly assigned to these four experimental conditions. The dependent variable was the evaluation of the candidate.

\section{Procedure}

All participants were informed that they were going totake part in a research designed to examine decision making processes in personnel selection. Participants completed a Qualtrics questionnaire with an estimated time for completion of less than five minutes, although it was specified that they could spend as long as they considered necessary. This questionnaire was presented with an introduction in which their participation was thanked and participants' informed consent was requested, indicating that their data would be treated in a completely anonymous and confidential way. Once this introductory information was received, participants were randomly assigned to one of the four possible experimental conditions. First, they were asked to read a brief text reflecting the context in which a fictitious organization found itself (favorable or unfavorable organizational context condition). After receiving information about the organization, a text was presented with the description of a candidate who was applying for a management position with high responsibility in that organization. The candidate was described in terms of high experience vs. potential, depending on the experimental condition. Then, all participants evaluated the candidate reporting their attitudes and hiring 
intentions to join the organization. These measures served to create a composite evaluation index of the candidate that was used as the dependent variable. Socio-demographic variables (gender and age) and previous experience (months worked until the time of study) were also recorded. Lastly, all participants were informed of what the main objectives of the study were, also offering them the possibility of expanding the information in relation to it. Therefore, participants were duly informed of all the conditions, measures, and a priori hypothesis.

\section{Independent variables}

Organizational context: Participants were randomly assigned to one of the two conditions of this independent variable. Specifically, participants read a brief text about the difficult economic situation of an organization and the scarce development opportunities and promotion of its employees (unfavorable organizational context) or about its economic prosperity and the prospects of growth of the employees (favorable organizational context). The message that was presented to participants only varied in certain keywords between the two conditions. In particular, the text of the favorable (vs. unfavorable) organizational context condition says: "Another year, the results reflect the growth (vs. weakening) in the organization, with an increase (vs. decrease) of turnover and number of sales and a decrease (vs. growth) of competitors. Employees enjoy excellent (vs. doubtful) prospects for the future."

Candidate description: Participants were randomly assigned to one of the two experimental conditions of this independent variable. In particular, participants were presented with a description of a candidate who was supposedly involved in a selection process to join the formerly described organization in a management position with high responsibility. Depending on the experimental condition, the candidate was described in terms of his high "experience" or his high "potential". The text that was presented to the participants only varied in certain keywords. The following is an excerpt from such text: "Luis is a candidate with great experience (vs. potential) in the field of human resources. His talent has provided (vs. can provide) critical value in any organization. All the people who have worked with him are certain that he has become (vs. can become) one of the most outstanding professionals in the sector."

\section{Dependent variables}

Attitudes towards the candidate: participants were asked to respond to three 10 -point Likert-scale items of attitudes. The items presented were the following: "From 1 to 10, indicate to what extent: 1 st. Do you consider the candidate to be a competent professional $(1=$ not at all competent; $10=$ fully competent); 2 nd. You'd hire him for the job. $(1=$ not at all; $10=$ totally $)$; 3 rd. You think he is a good person, $1=$ not at all; $10=$ totally). "The items presented a high internal consistency $(\alpha=.71)$, thus averaged to create a composite index. This index is a combination of indicators of behavioral attitudes and intentions, which are the best verbal predictors of overt behavior (e.g., Fishbein \& Ajzen, 1975). Higher score in this index indicates more favorable evaluations of the candidate.

In order to verify the predictive validity of our attitude measurement, a pilot Study was carried out in which thirtyseven students who participated voluntarily read an excerpt from a candidate's interview, in addition to his curriculum. In the interview excerpt, participants read the candidate's responses about his motivation for the job and his ability to perform satisfactorily. Participants also read the candidate's resume. Later, participants completed the same three measures of attitudes included in the main study.

The items showed a high internal consistency $(\alpha=$. 78). Participants then had the option of signing a document that supported the recruitment of the candidate's profile they had just read. This measure served as a behavioral indicator regarding the candidate. As expected, results showed a significant correlation between the measures of attitudes and the signature of that document, $r(36)=.475, p=.001$. In addition, an ANOVA was conducted including the dichotomous measurement of the document signature as a factor and the attitude index as a dependent variable. Results revealed a significant main effect of the dichotomous measurement of the document signature $\left(F(1,35)=10.20, p=.003, \eta_{\rho}^{2}=\right.$. 22). That is, participants in this pilot study who signed the document supporting the recruitment of the candidate had significantly more favorable attitudes $(M=7.16, S D=.71)$ than those who did not sign it $(M=6.11, S D=.86)$.

Professional Experience: Participants responded to the following question about their level of professional experience in personnel selection: "Please indicate the number of months of total experience in personnel selection." The answer format to this question was open, and it was operationalized as the number of months in order to analyze this data.

Ancillary measures. Participants reported their gender and age.

\section{Results}

Attitudes towards the candidate: The dependent variable was submitted to an analysis of variance (ANOVA) 2 (Organizational Context: Favorable vs. Unfavorable) X 2 (Candidate's Profile: Experience vs. Potential). The ANOVA did not yield significant main effects or the Organizational Context or the Candidate's Profile variable $\left(F(1,111)<3.19, p>.07, \eta_{\rho}{ }^{2}<\right.$ $.028)$. However, the analysis revealed a significant two-way interaction $\left(F(1,111)=7.716, p=.006, \eta_{\rho}^{2}=.065\right)$. As illustrated in Figure 1, in the unfavorable context condition, participants who read the description of the candidate based on his experience showed significantly more favorable attitudes $(M=7.42 ; S D=1.05)$ relative to those who read the description of the candidate based on his potential $(M=$ 6.42; $S D=0.97), F(1,111)=10.73, p=.001, \eta_{\rho}^{2}=.088$. In 
contrast, in the favorable organizational context condition, the candidate's evaluation did not significantly varied between those participants who read the description of the candidate based on his experience $(M=6.58 ; S D=1.67)$ and those who read description of the candidate based on his potential $(M=6.79 ; S D=0.81), F(1,111)=0.476, p=.49$, $\eta_{\rho}^{2}=.004$.

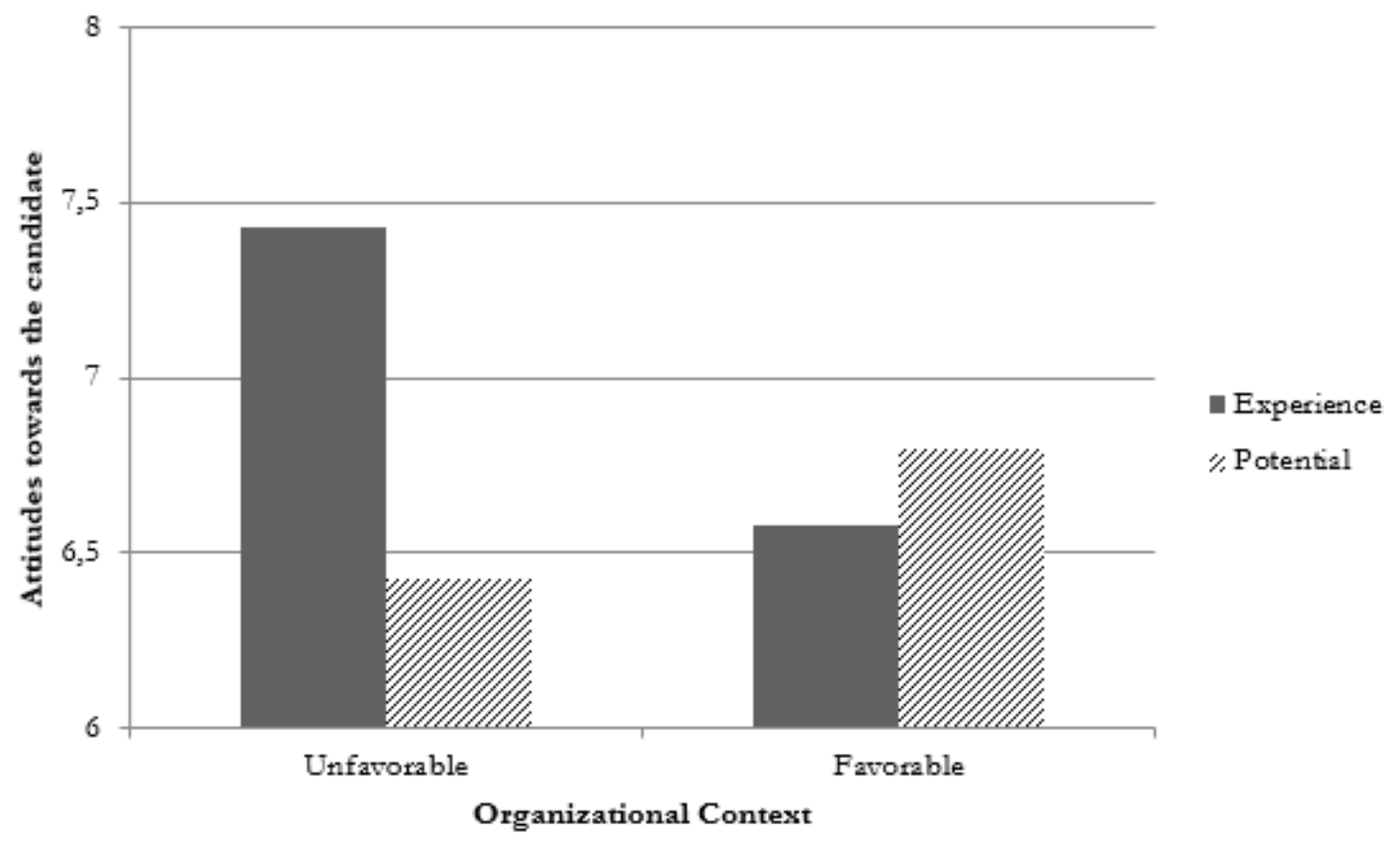

Figure 1. Attitudes towards the candidate as a function of organizational context and profile of the candidate.

In other words, in the experience-based profile condition, attitudes were significantly more favorable in the unfavorable organizational context condition $(M=7.42 ; S D=$ 1.05) relative to the favorable organization context condition $(M=6.58 ; S D=1.67), F(1,111)=8.045, p=.005, \eta_{\rho}^{2}=$ .068 . By contrast, among those participants who were assigned to read the description of the candidate based on his potential, those who were assigned to the unfavorable organizational context condition did not show significant differences in their attitudes $(M=6.42 ; S D=0.97)$ compared to those who were assigned to the favorable organizational context condition $(M=6.79 ; S D=0.81), F(1,111)=1.333, p=$ $.25, \eta_{\rho}^{2}=.012$.

Previous professional experience: Previous professional experience in personnel selection was recorded for all participants, with an average time of less than a year $(M=$ 9.02 months, $S D=14.71)$. As expected, total months of previous experience did not vary as a function of the experimental design. However, we controlled for the effect regarding the analysis previously described. Specifically, when the total months of previous experience was included as an additional predictor in the analysis (together with the two independent variables), no significant interactions were found, $B=-0.60, t(101)=-1.64, p=.10,95 \%$ CI: -1.3403 , 0.1252 , nor did it affect to the significance of the key interaction in this study.

Ancillary measures. The sample was composed of a $55.3 \%$ women with an average age of 24.99 years old $(S D=2.46)$. The same aforementioned procedure was followed to examine the impact of gender and age on the dependent measure. In other words, these two variables were included as additional predictors in the analyses. Again, none of these variables altered the significance obtained for the key two-way interaction between organizational context and candidate's profile, nor other significant interactions were observed ( $p \mathrm{~s}>$. 557).

\section{Discussion}

Results of this research are consistent with our initial predictions. In particular, under an unfavorable organizational context, recruiters assessed more positively the candidate with previous experience than the candidate with future potential. This preference for experience over potential appeared only under unfavorable organizational context conditions. However, under favorable organizational context conditions, this relationship was not found.

There would be several interpretations of the results found that would make predictions similar to our hypotheses. On the one hand, under unfavorable organizational context conditions people tend to look for certainty and a candidate with high experience might be considered a safer option than a candidate with high potential (Baumeister \& Jones, 1978; Briñol \& Petty, 2009; Erdogan, Kraimer, \& Li- 
den, 2004; Hogg, Meehan, \& Farquharson, 2010; McGregor \& Marigold, 2003). On the other hand, it could be that under unfavorable organizational context conditions the recruiters would have paid more attention to the characteristics of the candidates and considered that the previous experience constitutes a stronger merit than the promise of future potential, which could be seen as a relatively less strong argument. This interpretation is consistent with previous research in attitude change that shows that under unfavorable conditions people process information more carefully relative to favorable conditions (Briñol, Petty, \& Wheeler, 2006; Johnson, Petty, Briñol, \& See, 2017; for a recent review in Spanish on emotions and processing, see Briñol, Stavraki, Horcajo, \& Gandarillas, 2016).

Future research will discriminate between these two possible interpretations. For example, if our results show that the more unfavorable the context is, the greater the tendency of individuals to seek certainties through achievement or experience, one would expect that the effect obtained would be greater for people with low tolerance to uncertainty (Sorrentino \& Short, 1986; Kupor et al., 2014) or in a context of high need for cognitive closure (Webster \& Kruglanski, 1994; Horcajo, Gandarillas, Díaz, \& Briñol, 2011). On the other hand, if the unfavorable context increased the effect of the type of candidate through a processing mechanism then the effect could be expected to be greater for intermediate processing conditions (Briñol, Petty, Valle, Rucker, \& Becerra, 2007; Tiedens, \& Linton, 2001) and for candidates with greater differences among themselves (Briñol, Petty, \& Stavraki, 2012, Horcajo, See, Briñol, \& Petty, 2008). Depending on the type of moderator of the effect, it will be possible to specify with more precision the type of psychological mechanism by which the unfavorable context was associated with a greater discrimination between experience and potential.

Future research can also benefit from identifying possible differences between the favorable and unfavorable conditions studied in this research and other sources of doubt that have also been shown to increase the elaboration and processing of candidate characteristics, such as ambivalence, violation of expectations, surprise, threat and lack of power (Briñol \& Petty, 2009). In addition, future research should evaluate to what extent the contextual conditions studied in the present study would be associated with the discrimination of other characteristics of the candidates beyond differences between experience and potential, such as differences between curricula with many $v$ s. few merits, differences between real $v$ s. fictitious characteristics, and differences between honest candidates vs. liars (Briñol, Petty, \& Stavraki, 2012; Eisenkraft, Elfenbein, \& Kopelman, 2017; Ko, Sadler, \& Galinsky, 2015; Young, 2017). Moreover, additional dependent measures on attitudes towards the candidate and manipulation checks that would allow us to determine the extent to which manipulations can be associated with feel- ings of favorability (vs. unfavorability) or certainty (vs. uncertainty) could be included. The reason that these manipulation checks were not included is that if these items are presented too early in the procedure (e.g., before the main dependent variables), this could make the participants semantically prime with the concepts we want to manipulate, causing a bias in the results. On the other hand, if the manipulation checks are presented later in the procedure (e.g., after the dependent variables), this could dissipate the effects that the manipulations have on the sensations generated.

Furthermore, there are potential applications of the current research. On the one hand, the results obtained suggest that the evaluations of technicians, consultants and those responsible for recruitment are influenced by the organizational context under which they are at the time of the formation of their judgments. To the extent that the favorability of the context is perceived as a bias when evaluating candidates, it would be important to train the recruiters for correcting their bias (for another example of bias in personnel selection, see Horcajo, Brinol, \& Becerra, 2009). On the other hand, from the point of view of the possible candidates to the labor market, the results obtained suggest that it might be more effective to highlight the experience (instead of the potential) especially when candidates participate in recruitment processes for organizations that are operating under unfavorable contexts.

Finally, there are several limitations in the present research. On the one hand, despite showing an effect of preference for experience over potential under unfavorable conditions, this research does not provide empirical evidence on the process responsible for this effect (i.e., mediators of the effect) or the conditions upon which it is more or less likely to obtain this effect (i.e., moderators of the effect). The present research also does not offer evidence on the capacity to generalize the results to other populations, organizations and professional contexts. It is possible that different results may be found in other environments. For example, recent studies suggest that a person's potential may have a special value compared to experience and achievement in some circumstances. Tormala, Jia, and Norton (2012) showed that individuals prefer "potential" over "achievement" when evaluating other people in an experimental paradigm in which no information was provided about the favorability of the organizational context (for other examples of this possibility, see Kupor, Tormala, \& Norton, 2014; , Maheswaran \& Chaiken, 1991; Poehlman \& Newman, 2014Tiedens \& Linton, 2001; Wilson, Centerbar, Kermer, \& Gilbert, 2005). The results of these investigations suggest that, in contrast to the extensive literature that shows that individuals tend to seek certainty, as was indeed the case in the present study when the organizational context was unfavorable, the opposite is also possible if circumstances vary. 


\section{References}

Barnett, C. K., \& Pratt, M. G. (2000). From threat-rigidity to flexibilitytowards a learning model of autogenic crisis in organizations. Journal of Organizational Change Management, 13(1), 74-88, https://doi.org/10.1108/09534810010310258

Baumeister, R. F., \& Jones, E. E. (1978). When Self-presentation is constrained by the Target's knowledge: Consistency and compensation. Journal of Personality and Social Psychology, 36(6), 608-618, http://dx.doi.org/10.1037/0022-3514.36.6.608

Briñol, P., \& Petty, R. E. (2009). Persuasion: Insights from the self-Validation hypothesis. Advances In Experimental Social Psychology, 41, 69-118. https://doi.org/10.1016/S0065-2601 (08) 00402-4

Briñol, P., Petty, R. E., \& Stavraki, M. (2012). Power increases the reliance on first-impression thoughts. Journal of Social Psychology, 27(3), 293-303. http://dx.doi.org/10.1174/021347412802845513

Briñol, P., Petty, R. E., \& Wheeler, S. C. (2006). Discrepancies between explicit and implicit self-concepts: Consequences foR information Processing. Journal of personality and Social Psychology, 91(1), 154-170. http://dx.doi.org/10.1037/0022-3514.91.1.154

Brinol, P., Petty, R. E., Valle, C., Rucker, D. D., \& Becerra, A. (2007). The effects of message recipients ' power before and after persuasion: a self-validation analysis. Journal of personality and Social Psychology, 93(6), 1040-1053. http://dx.doi.org/10.1037/0022-3514.93.6.1040

Briñol, P., Stavraki, M., Horcajo, J., \&amp; Gandarillas, B. (2016). Emotion and persuasion. In I. Schweiger and J. R. Torregrosa (Eds.), Perspectives in the study of emotions (pp. 85-121). Madrid: Editorial Group 5.

Duncan, R. B. (1972). Characteristics of organizational environments and perceived environmental uncertainty. Administrative Science Quarterly, 313-327. http://dx.doi.org/10.2307/2392145

Eisenkraft, N., Elfenbein, H. A., \& Kopelman, S. (2017). We know who likes us, but not who competes against us: Dyadic meta-accuracy among work colleagues. Psychological Science, 28(2), 233-241. https://doi.org/10.1177/0956797616679440

Erdogan, B., Kraimer, M. L., \& Liden, R. C. (2004). Work value congruence and intrinsic career success: The compensatory roles of leader - member exchange and perceived organizational support. Personnel Psychology, 57(2), 305-332. https://doi.org/10.1111/j.1744-6570.2004.tb02493.x

Fishbein, M., \& Ajzen, I. (1975). Belief, attitude, intention, and behavior. Reading, Mass: Addison-Wesley.

Gertsen, M. C., Søderberg, A. M., \& Torp, J. E. (Eds.). (1998). Cultural dimensions of international mergers and acquisitions (Vol. 85). Walter de Gruyter.

Gärling, T., Kirchler, E., Lewis, A., \& Van Raaij, F. (2009). Psychology, financial decision making, and financial crises. Psychological Science in the Public Interest, 10 (1), 1-47. https://doi.org/10.1177/1529100610378437

Hart, J. (2014). Toward An integrative theory of psychological defense. Perspectives on Psychological Science, 9, 19-39. Doi: 10.1177/1745691613506018

Heine, S. J., Proulx, T., \& Vohs, K. D. (2006). The meaning Maintenance model: On The coherence of social motivations. Personality and Social Psychology Review, 10 (2), 88-110. Doi: 10.1207/S15327957pspr1002_1

Hogg, M. A. (2012). Uncertainty-Identity theory. In p. A. M. Van Lange, A. W. Kruglanski, \& E. T. Higgins (Eds.), Handbook of theories of social psychology (pp. $62-80)$. Thousand Oaks, CA: Sage.

Hogg, M. A., Meehan, C., \& Farquharson, J. (2010). The solace of radicalism: Self-uncertainty and group identification in the face of threat. Journal of Experimental Social Psychology, 46(6), 1061-1066. https://doi.org/10.1016/j.jesp.2010.05.005

Horcajo, J., Briñol, P., \& Becerra (2009). The effect of the Priming In the context of staff selection.Latin American Journal of Psychology, 41, 349359.

Horcajo, J., Díaz, D., Gandarillas, B., \& Briñol, P. (2011). Spanish adaptation of the Test of need for cognitive closure. Psychothema, 23(4), 864870 .

Horcajo, J., See, M., Briñol, P., \& Petty, R. E. (2008). The role of Mortality salience in consumer persuasion. Advances in Consumer Research, 35, 782783

Johnson, I. R., Petty, R. E., Briñol, P., \& See, y H. M. (2017). Persuasive message scrutiny as a function of implicit-explicit discrepancies in racial attitudes. Journal of Experimental Social Psychology, 70, 222-234. https://doi.org/10.1016/j.jesp.2016.11.007

Jonas, E., McGregor, I., KlacklJ. AgroskinD. Fritsche, I., Holbrook, C., Nash, K., Proulx, T., \& Quirin, M. (2014). Threat and Defense: From Anxiety to approach. In J. M. Olson \& M. P. Zanna (Eds.), Advances in experimental social psychology (Vol. 49, pp. 219-286). San Diego, Ca: Academic Press.

Kahneman, D., \& Tversky, A. (1979). Prospect theory: An Analysis of decision under risk. Econometrica: Journal of the Econometric Society, 263-291. https://doi.org/10.2307/1914185

Kay, A. C., Whitson, J. A., Gaucher, D., \& Galinsky, A. D. (2009). Compensatory Control: Achieving order through the mind, our InstitutIons, and the heavens. Current directions in Psychological Science, 18 (5), 264-268. Doi: https://doi.org/10.1111/J .1467-8721.2009.01649. x

Ko, S. J., Sadler, M. S., \& Galinsky, A. D. (2015). The Sound of Power: Conveying and detecting hierarchical rank through voice. Psychological Science, 26(1), 3-14. https://doi.org/10.1177/0956797614553009

Kruglanski, A. W. (1989). The psychology of being "right": the problem of accuracy in social perception and cognition. Psychological Bulletin, 106 (3), 395-409. http://dx.doi.org/10.1037/0033-2909.106.3.395

Kupor, D. M., Tormala, Z. L., \& Norton, M. I. (2014). The allure of unknown Outcomes: Exploring the role of uncertainty in the preference for potential. Journal of Experimental Social Psychology, 55, 210-216. https://doi.org/10.1016/j.jesp.2014.07.004

Leon, O. G., \& Montero, I. (2003). Methods of research in Psychology and Education (3rd ed.). Madrid: McGraw-Hill.

Maheswaran, D., \& Chaiken, S., (1991). Promoting systematic processing in low-motivation settings: Effect of incongruent information on processing and judgement. Journal of personality and Social Psychology 61, 1325. http://dx.doi.org/10.1037/0022-3514.61.1.13

Martin, L. L. (1999). I-D compensation Theory: Some Implications of Trying to Satisfy Immediate-return needs in a delayed-return Culture. Psychological Inquiry, 10 (3), 195. Doi: 10.1207/S15327965PLI1003_1

McGregor, I., \& Marigold, D. C. (2003). Defensive zeal and the uncertain self: What Makes You so sure? Journal of Personality and Social Psychology, 85(5), 838-852. http://dx.doi.org/10.1037/0022-3514.85.5.838

McGregor, I., Zanna, M. P., Holmes, J. G., \& Spencer, S. J. (2001). Compensatory conviction in the face Of personal uncertainty: Going to extremes and being oneself. Journal of Personality and Social Psychology, 80(3), 472-488. http://dx.doi.org/10.1037/0022-3514.80.3.472

Nash, K., McGregor, I., \& Prentice, M. (2011). Threat and defense as goal regulation: From Implicit goal conflict to anxious uncertainty, reactive approach motivation, and ideological extremism. Journal of Personality and Social Psychology, 101(6), 1291-1301. http://dx.doi.org/10.1037/a0025944

Nelson, S. C., \& Katzenstein, P. J. (2014). Uncertainty, risk, and the financial crisis of 2008. International Organization, 68 (2), 361-392. https://doi.org/10.1017/S0020818313000416

Poehlman, T. A., \& Newman, G. E. (2014). Potential: The Valuation of imagined future achievement. Cognition, 130 (1), 134-139. https://doi.org/10.1016/j.cognition.2013.10.003

Proulx, T. (2012). Threat-compensation in Social Psychology: Is There a Core motivation? Social Cognition, 30 (6), 643-651. Doi: 10.1521/Soco. 2012.30.6.643

Sorrentino, R. M., \& Short, J.-A. C. (1986). Uncertainty orientation, motivation, and cognition. In R. M. Sorrentino \& E. T. Higgins (Eds.), Handbook of Motivation and cognition: Foundations of Social behavior (pp. 379-403). New York: Guilford Press.

Rucker, D. D., Tormala, Z. L., Petty, R. E., \& Briñol, P. (2014). Consumer Conviction and Commitment: An Appraisal-based Framework For Attitude Certainty. Journal Of Consumer Psychology, 24 (1), 119-136. 
Thomas, M., \& Meno, G. (2007). When Internal reference prices and price expectations diverges: The role of confidence. Journal of Marketing Research, 44(3), 401-409. https://doi.org/10.1509/jmkr.44.3.401

Tiedens, L. Z., \& Linton, S., (2001). Judgment under emotional certainty and uncertainty: The effects of specific Emotions On information processing. Journal of Personality and Social Psychology, 81, 973-988. http://dx.doi.org/10.1037/0022-3514.81.6.973

Tormala, Z. L., \& Rucker, D. D. (2007). Attitude certainty: A review of past findings and emerging perspectives. Social and Personality Psychology Compass, 1 (1), 469-492. https://doi.org/10.1111/j.1751-9004.2007.00025.x

Tormala, Z., Jia, J. S., \& Norton, M. I. (2012). The preference for potential. Journal of Personality and Social Psychology, 103 (4), 567-583. http://dx.doi.org/10.1037/a0029227

Van den Bos, K., \& Lind, E. A. (2002). Uncertainty management by means of fairness judgments. In m. P. Zanna (Ed.), Advances in experimental social psychology (Vol. 34, pp. 1-60). San Diego, CA: Academic Press.
Wan, E. W., Rucker, D. D., Tormala, Z. L., \& Clarkson, J. J. (2010). The effect of regulatory depletion on attitude certainty. Journal of Marketing Research, 47 (3), 531-541. https://doi.org/10.1509/jmkr.47.3.531

Webster, D. M., \& Kruglanski, A. W. (1994). Individual differences in need for cognitive closure. Journal of Personality and Social Psychology, 67(6), 1049-1062. http://dx.doi.org/10.1037/0022-3514.67.6.1049

Wilson, T. D. Centerbar, d. B Kermer, A.D., \& Gilbert, D. (2005). The Pleasures of Uncertainty: Prolonging Positive moods in ways people do not anticipate. Journal of Personality and Social Psychology, 88, 5-21. http://dx.doi.org/10.1037/0022-3514.88.1.5

Young, S. G. (2017). An outgroup advantage in discriminating between genuine and possessed smiles. Self and Identity, 16(3), 298-312. http://dx.doi.org/10.1080/15298868.2016.1270851 